\section{Production of Bulbing Onion Overwintered in New Hampshire with Protection by Low Tunnels}

\author{
Rebecca Grube Sideman ${ }^{1,5}$, Amanda Brown ${ }^{2}$, Ruth Hazzard ${ }^{3}$, and \\ Heather Bryant ${ }^{4}$
}

ADDITIONAL INDEX wORDs. rowcover, season extension, Allium cepa

SumMARY. High demand for local produce year-round has led growers in the northeastern United States to experiment with fall planting of bulbing onion (Allium cepa) for spring harvest. Over two seasons, we evaluated survival, bolting, and bulbing of several cultivars of fall-planted onion in two sites in New Hampshire. Plants were seeded in August and September, and transplanted in September and October into raised beds covered with black plastic mulch. Low tunnels covered with $1.25-\mathrm{oz} / \mathrm{yard}^{2}$ rowcover and one layer of 6-mil-thick clear polyethylene were installed over the plants in late fall. Harvest dates ranged from 19 Apr. to 6 June in 2012, and from 22 May to 2 July in 2013. All onion cultivars showed high percentages of survival (65\% to $100 \%)$. Cultivar, planting date, and the interaction between the two had a significant effect on the percentage of bolting and bulb diameter at harvest. In general, those planted later exhibited lower percentages of bolting and slightly smaller bulbs at harvest. Our work demonstrates that it is possible to harvest large bulbed onions in May and June in the northeastern United States in U.S. Department of Agriculture (USDA) hardiness zones 4B and 5B using low-tunnel season extension technology. This may provide additional marketing opportunities for growers in cold climates.

$\mathrm{O}$ nion bulb formation is triggered by continued exposure to long days, and cultivars vary in the daylength required to initiate bulbing (Brewster, 2008). The daylength required is $\approx 16 \mathrm{~h}$ for long-day, 13-14 h for intermediateday, and $11-12 \mathrm{~h}$ for short-day cultivars (Brewster, 2008). Short-day onion cultivars are frequently planted in the fall for spring harvest in lower latitudes with mild winters; e.g., the southern United States (Boyhan et al., 2009;

Partial funding was provided by the New Hampshire Agricultural Experiment Station. This is Scientific Contribution Number 2552

We thank farm, greenhouse, and technical staff at the University of New Hampshire and at the Grafton County Farm for technical assistance. We also thank Cathy Neal, Mark Hutton, and Nicholas Warren for providing thoughtful reviews of our manuscript.

${ }^{1}$ Department of Biological Sciences, University of New Hampshire, 38 Academic Way, Durham, NH 03824

${ }^{2}$ Stockbridge School of Agriculture, University of Massachusetts, 301 Agricultural Engineering Building, 250 Natural Resources Road, Amherst, MA 01003

${ }^{3}$ University of Massachusetts Extension, 301 Agricultural Engineering Building, 250 Natural Resources Road, Amherst, MA 01003

${ }^{4}$ University of New Hampshire Cooperative Extension, 3855 Dartmouth College Highway, North Haverhill, NH 03774

${ }^{5}$ Corresponding author. E-mail: becky.sideman@unh. edu.
Brewster, 2008; Corgan et al., 2000; Cramer, 2003). In higher latitudes, long-day cultivars are typically planted during the spring (April or May) for late summer (August or September) harvest, and in middle latitudes, intermediate-day cultivars can be grown as fall-planted overwintered crops. Research conducted in Oregon (zone $8 \mathrm{~b}$, lat. $45^{\circ} \mathrm{N}$ ) demonstrated that onion crops could be successfully overwintered to produce marketable onions in the spring [Hemphill, 1987; USDA, 2012]. Fall planting of onion has been extensively researched in the United Kingdom, where it has successfully been grown as an overwintered crop. The United Kingdom has mild winter temperatures that correspond to USDA hardiness zones 8a to 9a (Rice 2010) at high latitudes, over $50^{\circ} \mathrm{N}$ (Allen et al., 1978; Brewster et al., 1977).

According to Brewster (2008), onion plants are killed by minimum temperatures of -8 to $-11^{\circ} \mathrm{C}$. Corgan et al. (2000) also reports that some plant loss occurs at $12^{\circ} \mathrm{F}$, with higher mortality at lower temperatures and for smaller and younger plants. In artificial frosting experiments, Gill and Waister (1983) found good survival even when plots experienced temperatures as low as $-19.4{ }^{\circ} \mathrm{C}$. Weak plants were more frequently damaged by cold temperatures, and frost heaving was proposed to be a major cause of winter mortality.

Because bolting, or the production of a flower stalk, results in a hard scape in the center of the bulb and reduces bulb size, it is undesirable during the production of bulbing onions. Bolting is triggered by vernalization or prolonged exposure to cool temperatures once the onion plant has reached a critical size (Pike, 1986; Streck, 2012). This critical plant size varies with cultivar, ranging from 7 to 10 or more true leaves (Brewster 2008). Streck (2012) defines the minimum, optimum, and maximum vernalization temperatures as 0,10 , and $16{ }^{\circ} \mathrm{C}$, respectively. The duration of exposure to these temperatures can be described in terms of vernalization days (VD) or the cumulative exposure to suitable temperatures for $24 \mathrm{~h}$ (Streck 2012). According to the model of Streck (2012), vernalization requires at least $17 \mathrm{VD}$ and is complete by 60 VD. Devernalization can also occur, when vernalized onion plants or bulbs are exposed to temperatures of 21 and $35^{\circ} \mathrm{C}$ (Baldwin et al., 2014; Brewster, 2008).

\begin{tabular}{llll}
\hline $\begin{array}{l}\text { Units } \\
\text { To convert U.S. to SI, } \\
\text { multiply by }\end{array}$ & U.S. unit & SI unit & $\begin{array}{l}\text { To convert SI to U.S., } \\
\text { multiply by }\end{array}$ \\
\hline 0.4047 & acre $(\mathrm{s})$ & $\mathrm{ha}$ & $2.471 \mathrm{l}$ \\
29.5735 & $\mathrm{fl} \mathrm{oz}$ & $\mathrm{mL}$ & 0.0338 \\
0.3048 & $\mathrm{ft}$ & $\mathrm{m}$ & 3.2808 \\
3.7854 & gal & $\mathrm{L}$ & 0.2642 \\
2.54 & inch(es) & $\mathrm{cm}$ & 0.3937 \\
25.4 & inch(es) & $\mathrm{mm}$ & 0.0394 \\
1.1209 & lb/acre & $\mathrm{kg} \cdot \mathrm{ha}^{-1}$ & 0.8922 \\
0.0254 & mil & $\mathrm{mm}$ & 39.3701 \\
28.3495 & $\mathrm{oz}$ & $\mathrm{g}$ & 0.0353 \\
33.9057 & $\mathrm{oz} / \mathrm{yard}^{2}$ & $\mathrm{~g} \cdot \mathrm{m}^{-2}$ & 0.0295 \\
$\left({ }^{\circ} \mathrm{F}-32\right) \div 1.8$ & ${ }^{\circ} \mathrm{F}$ & ${ }^{\circ} \mathrm{C}$ & $\left({ }^{\circ} \mathrm{C} \times 1.8\right)+32$
\end{tabular}

Hortlechnology · December 2014 24(6) 
Because fall planting exposes onion plants to ideal vernalization conditions, resistance to bolting is an important criterion for cultivars used in overwintering systems (Brewster 1982, Cramer 2003). Several Japanese cultivars with high resistance to bolting have been shown to be well adapted to overwintering systems (Bosch Serra and Currah, 2002; Gill and Waister, 1983).

Planting date has been shown to affect both survival and bolting (Brewster, 2008; Corgan and Keder, 1990). In general, later fall planting dates have been shown to not only reduce plant survival but also minimize spring bolting. However, the unpredictability of fall temperatures makes it difficult to define an ideal seeding date to balance these tradeoffs (Brewster et al., 1977).

In the northeastern United States, increased demand for fresh locally produced vegetables throughout winter and spring provides a possible market for hardy overwintering fresh market vegetables. This has led growers in the region to experiment with fall planting of bulbing onion for spring harvest. While some have reported good success, others have reported challenges including poor survival, frost or freeze damage, and high percentages of bolting.
Winter temperatures in New England routinely fall well below the temperatures that can cause mortality in onion. In previous work, we have shown that inexpensive low tunnels over field production can mitigate the coldest winter temperatures and that soil rarely freezes under low tunnel coverings (Sideman et al., 2012). Our objective was to evaluate whether onion cultivars could be successfully overwintered in low tunnels for spring harvest and marketing in New England. In this manuscript, we describe the results of our experiments evaluating survival, bolting, and yields of fall-planted onion over two seasons at two sites in New Hampshire.

\section{Methods}

Cultivars and Cultural PRACTICES. The 11 onion cultivars that were planted in one or more of the three experiments conducted are shown in Table 1, along with seed sources and descriptions of each cultivar. We evaluated intermediate-day cultivars bred for very early spring production or for overwintering (Bridger, Keepsake, Top Keeper, and T-420), as well as a long-day cultivar adapted to spring and summer production in northern latitudes (Walla Walla), and a nonbulbing scallion (Allium fistulosum cv. Winter

Table 1. Sources and descriptions of onion cultivars used in overwintering experiments in New Hampshire in 2011-12 and 2012-13.

\begin{tabular}{lll}
\hline Cultivar & \multicolumn{1}{c}{ Source $^{\mathrm{z}}$} & \multicolumn{1}{c}{ Description } \\
\hline Bridger & Johnny's & Early yellow storage onion, intermediate day \\
Keepsake & Territorial & Yellow storage onion, intermediate day \\
T-420 & Johnny's & Yellow storage onion, intermediate day \\
Top-Keeper & Territorial & Yellow storage onion, intermediate day \\
Walla Walla & Seedway, Johnny's & Yellow sweet onion, long day \\
Winter White & Territorial & White scallion, nonbulbing
\end{tabular}

'Johnny's = Johnny's Selected Seeds (Albion, ME), Territorial = Territorial Seeds (Cottage Grove, OR), Seedway = Seedway Vegetable Seeds (Elizabethtown, PA).
White). The intermediate- and longday cultivars were included because of grower interest and availability, and Winter White scallion was chosen because of known winterhardiness. Dates of seeding, transplanting, and other experimental procedures are presented in Table 2. Plants were seeded in an unheated greenhouse in 98-cell transplant trays, were thinned to single plants, and were transplanted outdoors with an in-row spacing of 6 inches with three rows 6 inches apart on raised beds covered with embossed 1-mil-thick black plastic mulch. Raised beds were 30 inches wide, and spaced $7 \mathrm{ft}$ between centers. Drip irrigation tape was laid under each row, but irrigation was not used throughout the course of these experiments. At each location, fertilizers were applied before bed formation according to commercial recommendations for onion according to Howell and Hazzard (2011) based on annual soil tests. In Durham, this resulted in applications of nitrogen at a rate of $100 \mathrm{lb} /$ acre and potassium at a rate of $150 \mathrm{lb} /$ acre using a combination of soybean meal $(6 \mathrm{~N}-0.4 \mathrm{P}-0.8 \mathrm{~K})$ and sulfate of potash-magnesium $(0 \mathrm{~N}-0 \mathrm{P}-18.3 \mathrm{~K})$. The North Haverhill site had high preplant soil nutrient levels, and as a result, each plant received $3.8 \mathrm{fl} \mathrm{oz}$ of diluted starter solution $(8 \mathrm{~N}-19.7 \mathrm{P}-11.6 \mathrm{~K}$ diluted at a rate of $4.4 \mathrm{oz}$ per $10 \mathrm{gal})$. Weeds between rows were controlled mechanically.

Low tunnels made of $10-\mathrm{ft}$ polyvinyl chloride conduit or bent electrical metallic tubing bows were installed over the plants in late fall. The resulting 3.5- $\mathrm{ft}$ tall low tunnels were covered with $1.25 \mathrm{oz} /$ yard $^{2}$ rowcover (Dupont 5131; Autoverters, Roanoke Rapids, NC) shortly after the first frost, and an additional layer of 6mil-thick polyethylene (SunMaster Greenhouse Film; Lumite, Alto, GA)

Table 2. Dates of specific activities in overwintering onion experiments in 2011-12 and 2012-2013.

\begin{tabular}{|c|c|c|c|c|c|c|c|c|c|c|}
\hline Yr & Location & Planting & $\begin{array}{l}\text { Seeding } \\
\text { date }\end{array}$ & $\begin{array}{c}\text { Transplant } \\
\text { date }\end{array}$ & $\begin{array}{c}\text { Rowcover } \\
\text { added } \\
\text { date }^{\mathrm{z}}\end{array}$ & $\begin{array}{l}\text { Plastic } \\
\text { added } \\
\text { date }\end{array}$ & $\begin{array}{c}\text { Plastic } \\
\text { removed } \\
\text { date }\end{array}$ & $\begin{array}{c}\text { Rowcover } \\
\text { removed } \\
\text { date }\end{array}$ & $\begin{array}{c}\text { Assessed } \\
\text { survival } \\
\text { date }\end{array}$ & $\begin{array}{c}\text { First } \\
\text { harvest } \\
\text { date }\end{array}$ \\
\hline \multirow[t]{2}{*}{$2011-12$} & Durham, NH & Early & 18 Aug. & 20 Sept. & 18 Oct. & 16 Dec. & 14 Mar. & 5 Apr. & 12 May & 12 May \\
\hline & & Late & 18 Aug. & 30 Sept. & 18 Oct. & $16 \mathrm{Dec}$. & 14 Mar. & 5 Apr. & 12 May & 12 May \\
\hline \multirow[t]{2}{*}{$2012-13$} & Durham, NH & Early & 25 Aug. & 20 Sept. & 20 Oct. & 20 Oct. & 15 Apr. & 15 Apr. & 30 Apr. & 22 May \\
\hline & & Late & 15 Sept. & 20 Oct. & 20 Oct. & 20 Oct. & 15 Apr. & 15 Apr. & 30 Apr. & 22 May \\
\hline
\end{tabular}

${ }^{2}$ Rowcover was $1.25-\mathrm{oz} / \mathrm{yard}^{2}\left(42.4 \mathrm{~g} \cdot \mathrm{m}^{-2}\right)$ polypropylene and plastic was 6 -mil-thick $(0.152 \mathrm{~mm})$ clear polyethylene. Both were installed over bows to create low tunnels $\approx 3.5 \mathrm{ft}(1.07 \mathrm{~m})$ high. 
was added for the winter, once night time temperatures reached $\approx 20{ }^{\circ} \mathrm{F}$. We had planned to remove the low tunnels in early April, but the abnormally early warm spring in 2012 resulted in high temperatures in March, so the plastic was removed in mid-March to avoid heat damage. In year two (2012-13), an uncovered treatment was included.

LOCATION/CLIMATE. Experiments were conducted in Durham, NH, at the New Hampshire Agricultural Experiment Station (lat. $43.13^{\circ} \mathrm{N}$, long. $\left.70.93^{\circ} \mathrm{W}\right)$, and in North Haverhill, $\mathrm{NH}$, at the Grafton County Farm (lat. $44.09^{\circ} \mathrm{N}$, long. $\left.72.03^{\circ} \mathrm{W}\right)$. North Haverhill is in USDA hardiness zone $4 \mathrm{~B}$ and Durham is zone $5 \mathrm{~B}$ (USDA, 2012). In year one of our study (2011-12), experiments were conducted in Durham only. On the basis of the results in year one, North Haverhill, a colder site, was added in year two (2012-13).

Experimental Design. Experimental units ranged from 24 to 30 plants, and four blocks were included in all experiments. In year one in Durham, a split plot design was used, where cultivar was the main factor and planting date was the split plot factor. In year two in Durham and North Haverhill, a split-split plot design was used, where covering (low tunnel vs. none) was the whole plot factor, cultivar was the split plot factor, and planting date was the split-split factor.

DATA COLleCtion AND ANALYSIS. Temperature data were collected outdoors and inside low tunnels using thermocouples (TMC6-HD; Onset Computer Corp., Bourne, MA) connected to four-channel outdoor data loggers (Hobo U12-008, Onset Computer Corp.). Air and soil temperature were monitored in all experiments.
Temperatures were logged at intervals of $2 \mathrm{~h}$. Air temperature probes were shielded from sunlight and placed $30 \mathrm{~cm}$ above the soil surface. Soil temperature was recorded at a depth of $4 \mathrm{~cm}$ in the center of raised beds. Three thermocouples were used to collect each measurement in each experiment, and the three values were checked for outliers, and then averaged. To calculate duration of exposure to vernalization temperatures, the equation described by Streck (2012) was used to calculate the amount of effective vernalization hours attained during each 2 -h period throughout the experiment: $\left[2 \times \mathrm{T}^{\alpha} \times 10^{\alpha}-\right.$ $\left.\mathrm{T}^{2 \alpha}\right] / 10^{2 \alpha}$, where $\alpha=1.47477$ and $\mathrm{T}$ was the air temperature measured, between 0 and $16^{\circ} \mathrm{C}$. This results in fewer effective vernalization hours at temperatures near the end of this range than at the optimum, $10{ }^{\circ} \mathrm{C}$. The number of VDs was then calculated by dividing by 12 .

Percent survival was evaluated for each experiment after the low tunnels were removed in the spring, on dates ranging from 24 Apr. to 12 May (Table 2). Percentage of bolted plants was evaluated on 12 May in Durham in 2012, and on 22 May in both Durham and North Haverhill in 2013 .

In all experiments, randomly selected subsamples of six bulbs per plot were harvested at each of three harvest dates, ranging from early May through late June. The first harvest occurred when at least one cultivar showed sufficient bulb development to be marketable as a fresh onion, which corresponded to a bulb:neck ratio of 2.4 or greater. Bulb and neck diameter were measured, and the bulb:neck ratio was calculated for each bulb. Percentage of bolting was reassessed at each harvest date, and because the percentage of bolted plants did not change, the original data from mid-May are presented.

The effects of cultivar, planting date, and their interaction on percent survival, percent bolting, and bulb diameter were analyzed by analysis of variance (ANOVA) using JMP Pro 11 (SAS Institute, Cary, NC). Frequency data (survival, bolting) were arcsinetransformed before performing ANOVA. Least squared means were then backtransformed for presentation of results. When the cultivar $\times$ planting date interaction was significant, results from each planting date were then analyzed and presented separately When the overall $\mathrm{F}$ test was significant $(P \leq 0.05)$, differences between treatments were evaluated using Tukey's honestly significant difference tests at the $P \leq 0.05$ level.

\section{Results \\ Environment}

Throughout the experiment, winter minimum temperatures did not reach the extreme low temperatures that define USDA hardiness zones for either site. In 2011-12, the minimum outdoor air temperature was $-23.2^{\circ} \mathrm{C}$ in Durham, and in 2012-13, minimum outdoor temperatures were -19.7 and $-28.2{ }^{\circ} \mathrm{C}$ in Durham and North Haverhill, respectively (Table 3 ). While 2012-13 spring temperatures were typical, the 2011-12 growing season was abnormally advanced, with record warm temperatures during the early spring. For example, 250 growing degree days (base temperature $=50^{\circ} \mathrm{F}$ ) had accumulated on 12 May 2012, while that value was not reached until 30 May 2013.

The temperatures measured under low tunnels were much higher than those measured outdoors

Table 3. Minimum monthly air and soil temperatures in low tunnels and outdoors during Winter 2011-12 and 2012-13 at two New Hampshire locations.

\begin{tabular}{|c|c|c|c|c|c|c|c|c|c|c|c|c|}
\hline \multirow[b]{3}{*}{ Season } & \multirow[b]{3}{*}{ Location } & \multirow[b]{3}{*}{ Site } & \multicolumn{10}{|c|}{ Minimum temp $\left({ }^{\circ} \mathbf{C}\right)^{\mathrm{z}}$} \\
\hline & & & \multicolumn{2}{|c|}{ November } & \multicolumn{2}{|c|}{ December } & \multicolumn{2}{|c|}{ January } & \multicolumn{2}{|c|}{ February } & \multicolumn{2}{|c|}{ March } \\
\hline & & & Air & Soil & Air & Soil & Air & Soil & Air & Soil & Air & Soil \\
\hline & & Outdoors & -7.1 & -0.1 & -13.2 & -4.6 & -23.2 & -8.3 & -12.4 & -7.3 & -13.5 & -1.0 \\
\hline \multirow[t]{2}{*}{$2012-13$} & Durham, NH & Low Tunnel & -7.4 & 1.1 & -8.3 & 0.6 & -13.8 & 0.1 & -8.4 & 0.6 & -7.9 & 2.2 \\
\hline & & Outdoors & -6.5 & 0.2 & -10.2 & 0.1 & -19.7 & -2.4 & -14.0 & -5.0 & -11.0 & -0.1 \\
\hline
\end{tabular}

${ }^{\mathrm{z}}\left(1.8 \times{ }^{\circ} \mathrm{C}\right)+32={ }^{\circ} \mathrm{F}$.

The low tunnel was covered with $1.25-\mathrm{oz} / \mathrm{yard}^{2}\left(42.4 \mathrm{~g} \cdot \mathrm{m}^{-2}\right)$ polypropylene rowcover and 6-mil-thick $(0.152 \mathrm{~mm})$ clear polyethylene. 
(Table 3). The minimum temperatures reached under low tunnels were as much as $13{ }^{\circ} \mathrm{C}$ warmer than the minimum outdoor temperatures; this difference was greater at the coldest outdoor temperatures. Despite very cold air temperatures outdoors, the air temperatures inside low tunnels never fell below $-17^{\circ} \mathrm{C}$ in any of the experiments.

A similar trend was observed for soil temperatures (Table 3 ). The minimum soil temperature inside low tunnels remained just around freezing $\left(0{ }^{\circ} \mathrm{C}\right)$, while outdoor soil temperatures averaged less than $0^{\circ} \mathrm{C}$ and occasionally dropped to below $-8^{\circ} \mathrm{C}$.

The accumulation of temperatures critical to onion development in each experiment is shown in Fig. 1. Vernalization temperatures $\left(0-16^{\circ} \mathrm{C}\right)$ accumulated to higher levels under low tunnels than outdoors. Some accumulation took place in the fall
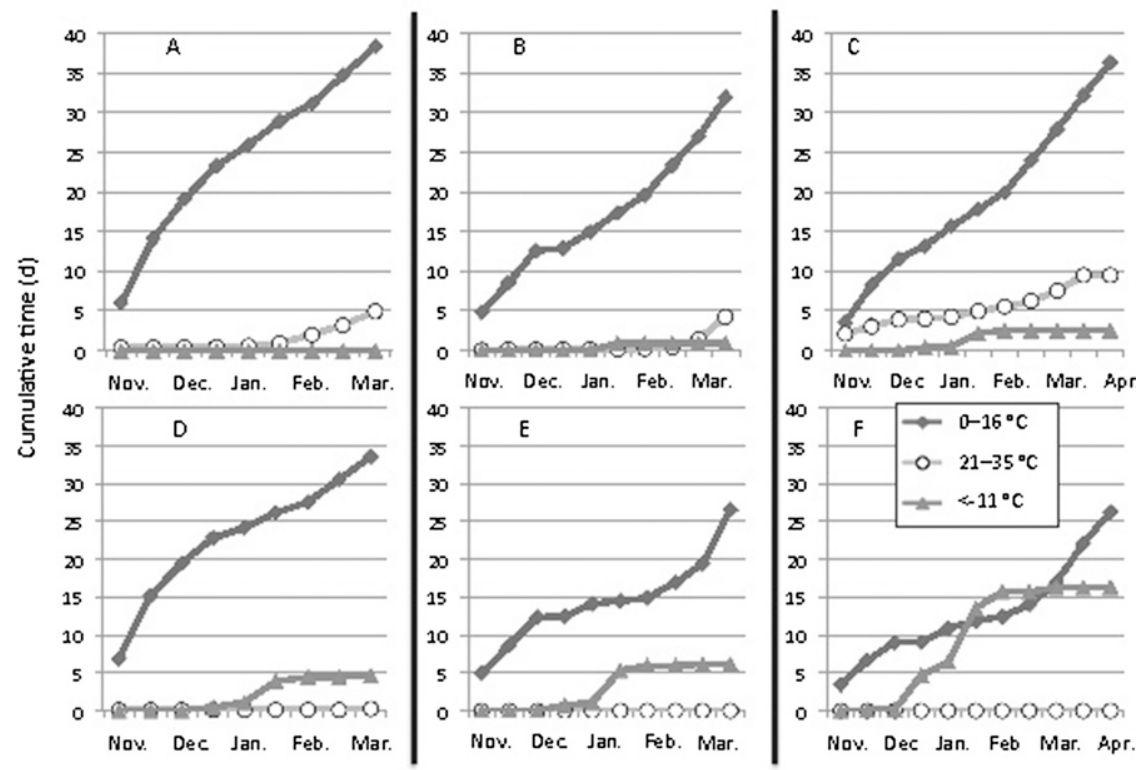

Fig. 1. Cumulative time during winter months at which air temperatures were within the ranges that can cause vernalization $\left(0-16^{\circ} \mathrm{C}\right)$, devernalization $\left(21-35^{\circ} \mathrm{C}\right)$, or mortality (below $\left.-11^{\circ} \mathrm{C}\right)$ in onion: $(\mathrm{A}, \mathrm{B}$, and $\mathrm{C})$ duration of air temperatures under low tunnels, $(\mathrm{D}, \mathrm{E}$, and $\mathrm{F})$ duration of air temperatures outdoors. Data were collected from 1 Nov. 2011 to 15 Mar. 2012 in Durham, NH (A, D), and 1 Nov. 2012 through 9 Apr. 2013 in Durham (B, E), and North Haverhill, $\mathrm{NH}(\mathrm{C}, \mathrm{F}) ;\left(1.8 \times{ }^{\circ} \mathrm{C}\right)+32={ }^{\circ} \mathrm{F}$.

(primarily November), but most took place in the early spring. More VD accumulated during 2011-12 than in 2012-13. Onion plants in low tunnels (but not outdoors) were exposed to temperatures at which devernalization can occur $\left(2 \mathrm{l}-35^{\circ} \mathrm{C}\right)$ in early spring. Outdoor onion plants experienced a longer duration of temperatures below $-11{ }^{\circ} \mathrm{C}$, which can cause mortality, than those in low tunnels.

\section{Onion survival under low tunnels}

When grown under low tunnels, the percentage of survival was high for all cultivars in all experiments, and no significant differences were observed between cultivars in any experiment (Table 4). Further, no significant differences were observed for survival between transplant dates, despite more than $20 \mathrm{~d}$ difference in transplant dates in 2012-13, for both sites.

\section{Bolting}

The percentage of bolting observed varied greatly between experiment, cultivar, and planting date (Table 5 ).

2011-12. Across both planting dates, the average percentage of bolted plants ranged from $19.3 \%$ for 'Bridger' to $98.8 \%$ for 'Walla Walla', which was significantly higher than all other cultivars in the experiment. Planting date also had an effect on bolting; those plants transplanted just 10 d later (on 30 Sept. vs. 20 Sept.) exhibited significantly less bolting

Table 4. Mean percentage of overwinter survival of fall-planted onion in two seasons and two New Hampshire locations in low tunnels or grown outdoors unprotected.

\begin{tabular}{|c|c|c|c|c|c|}
\hline & \multicolumn{5}{|c|}{ Mean percentage survival $(\%)^{\mathrm{z}}$} \\
\hline & \multirow{3}{*}{$\frac{\frac{2011-12}{\text { Durham, } \mathrm{NH}}}{\frac{\text { Low tunnel }}{}}$} & \multicolumn{4}{|c|}{$2012-13$} \\
\hline & & \multicolumn{2}{|c|}{ Durham, NH } & \multicolumn{2}{|c|}{ North Haverhill, NH } \\
\hline & & Low tunnel & Outdoors & Low tunnel & Outdoors \\
\hline \multicolumn{6}{|l|}{ Cultivar } \\
\hline Bridger & 100 & 85.4 & 38.3 & 98.5 & 95.6 \\
\hline Keepsake & 99.9 & 91.9 & 31.6 & $-^{y}$ & - \\
\hline Walla Walla & 99.4 & 79.5 & 41.8 & 97.3 & 84.7 \\
\hline Winter White & 98.3 & 64.8 & 44.1 & - & - \\
\hline \multicolumn{6}{|l|}{ Analysis of variance ${ }^{\mathrm{x}}$} \\
\hline Cultivar & NSD & NSD & NSD & NSD & NSD \\
\hline Transplant date & NSD & NSD & NSD & NSD & NSD \\
\hline
\end{tabular}

${ }^{z}$ Survival was assessed between 24 Apr and 12 May in each experiment.

${ }^{y}$ Cultivar or factor not included in this experiment.

${ }^{x} \mathrm{NSD}=$ no significant differences detected, ${ }^{* *} P<0.001,{ }^{*} P<0.01,{ }^{*} P<0.05$. 
[39.9\% compared with $63.3 \%(P<$ $0.001)]$.

2012-13. In both sites, there was a strong cultivar $\times$ planting date interaction. No bolting was observed in the later transplant date (20 Oct.). In the earlier date, a low (but statistically significant) percentage of bolting was observed for 'Walla Walla' (3.6\%), while very little or no bolting was observed for all other cultivars.

\section{Bulbing}

All plants that survived the winter and that did not bolt produced large bulbs that would be considered marketable as fresh onions in our direct-market conditions.

2011-12. In Durham, bulb size increased over time until the final harvest on 6 June, when the largest bulbs were over $80 \mathrm{~mm}$ in diameter (Table 6). Significant differences were detected due to cultivar and planting date; and on the final date, the cultivar $\times$ planting date interaction was significant. Although most cultivars produced large bulbs, Winter White and Walla Walla consistently had the smallest bulbs, with bulb diameters remaining less than $60 \mathrm{~mm}$. The remaining four cultivars, Bridger, Keepsake, T-420, and Top Keeper, were not significantly different from one another. At all harvest dates, bulbs from plants that were transplanted

Table 5. Mean percentage of bolting observed for fall-planted onion grown under low tunnels in two seasons, at two New Hampshire locations, and two planting dates.

\begin{tabular}{|c|c|c|c|c|c|c|}
\hline & \multicolumn{6}{|c|}{ Mean bolting $(\%)^{\mathrm{z}}$} \\
\hline & \multirow{2}{*}{\multicolumn{2}{|c|}{$\begin{array}{c}2011-12 \\
\text { Durham, NH }\end{array}$}} & \multicolumn{4}{|c|}{$2012-13$} \\
\hline & & & \multicolumn{2}{|c|}{ Durham, NH } & \multicolumn{2}{|c|}{ North Haverhill, NH } \\
\hline & Early $^{\mathrm{y}}$ & Late & Early & Late & Early & Late \\
\hline \multicolumn{7}{|l|}{ Cultivar } \\
\hline Bridger & $23.3 c^{x}$ & $15.9 \mathrm{~b}$ & $0 \mathrm{~b}$ & 0 & $0 \mathrm{~b}$ & 0 \\
\hline Keepsake & $50.0 \mathrm{bc}$ & $19.7 \mathrm{~b}$ & $0 \mathrm{~b}$ & 0 & - $^{\mathrm{w}}$ & - \\
\hline Walla Walla & $99.3 \mathrm{a}$ & $97.7 \mathrm{a}$ & $5.2 \mathrm{a}$ & 0 & $3.6 \mathrm{a}$ & 0 \\
\hline Winter White & $46.0 \mathrm{bc}$ & $27.3 \mathrm{~b}$ & $0.3 \mathrm{ab}$ & 0 & - & - \\
\hline \multicolumn{7}{|l|}{ Analysis of variance ${ }^{v}$} \\
\hline Cultivar & \multicolumn{2}{|c|}{$* * *$} & \multicolumn{2}{|c|}{$* * *$} & \multicolumn{2}{|c|}{ * } \\
\hline Transplant date & \multicolumn{2}{|c|}{$* * *$} & \multicolumn{2}{|c|}{$* * *$} & \multicolumn{2}{|c|}{ * } \\
\hline
\end{tabular}

${ }^{\mathrm{z}}$ Bolting was assessed between 22 May and 6 June in all experiments.

y Results for each planting date are presented separately. The early and late planting dates were 20 Sept. and 30 Sept. in Durham in $2011-12,20$ Sept. and 20 Oct. in Durham in $2012-13$, and 11 Oct. and 21 Oct. in North Haverhill, respectively.

${ }^{x}$ Within a column, means followed by the same letter are not significantly different at $P \leq 0.05$ using Tukey's honestly significant difference test.

"Cultivar or factor not included in this experiment.

${ }^{\mathrm{N} S \mathrm{~N}}=$ no significant differences detected, ${ }^{* *} P<0.001,{ }^{*} P<0.01,{ }^{*} P<0.05$.

Table 6. Mean bulb diameter for several cultivars of fall-planted onion grown in low tunnels from two plantings in Durham, $\mathrm{NH}$, in the 2011-12 season.

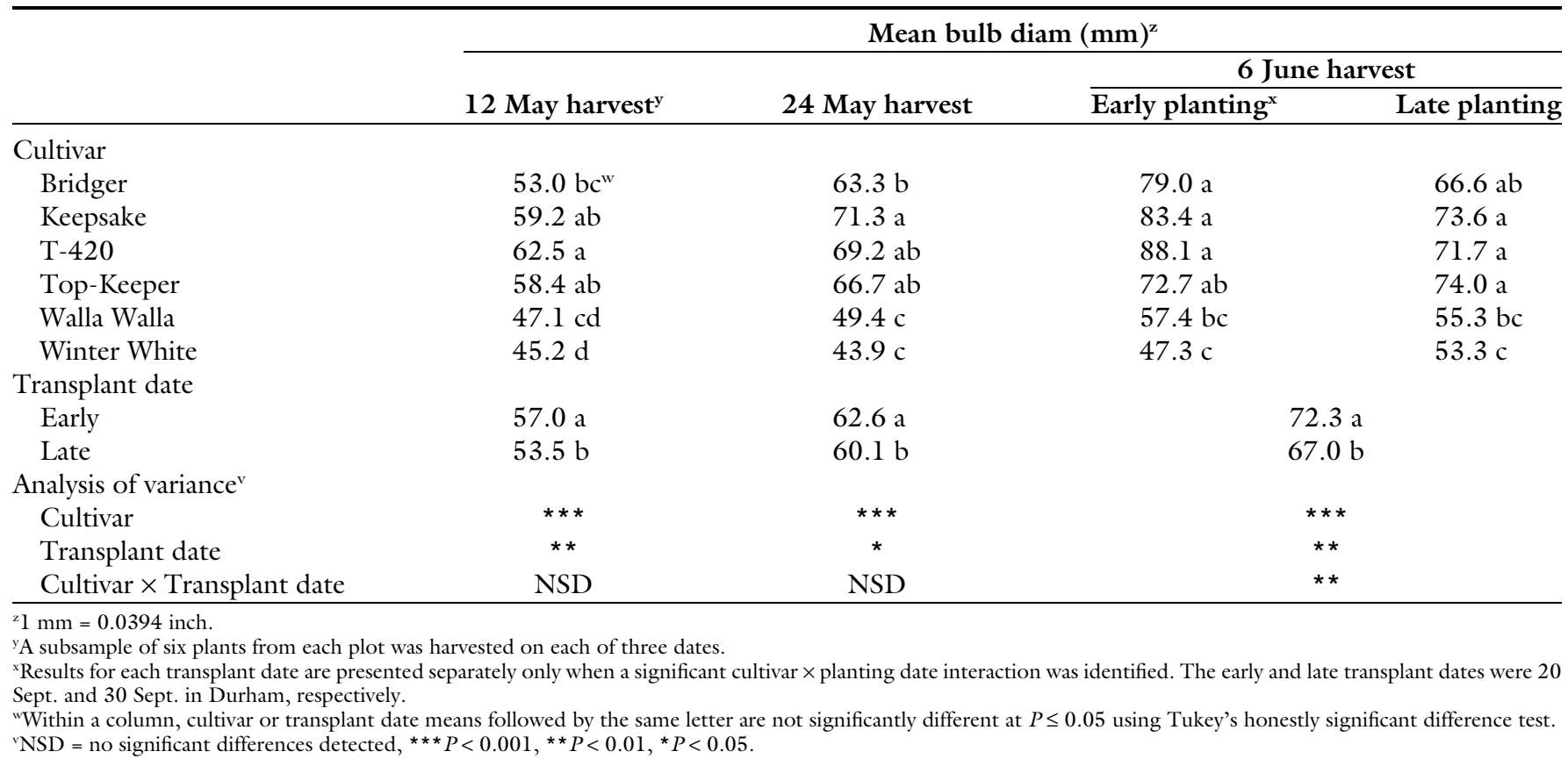


earlier (20 Sept.) were larger than those transplanted later (30 Sept.).

2012-13. In Durham, cultivar, planting date, and the interaction between these factors all influenced bulb size on all harvest dates (Table 7 ). As in 2011-12, at all harvest dates, bulb size was larger for the earlier transplant date. 'Winter White' scallion consistently had the smallest bulbs. The yellow intermediate-day cultivars Keepsake, T-420, and TopKeeper had the largest bulbs throughout the experiment. For the late transplant date, 'Bridger' produced bulbs that were not significantly different from these cultivars, while the early-planted 'Bridger' bulbs were smaller, throughout all harvest dates. While for earlier harvests, 'Walla Walla' bulbs were smaller than those of other cultivars, Walla Walla bulbs were among the largest at the final harvest.

\section{Onion survival and growth without low tunnels}

In 2012-13, onion plants grown outdoors over winter did not survive well in Durham (38\% to 44\% survival, depending on cultivar), but showed high percentages of survival $(85 \%$ to 96\%) in North Haverhill (Table 4). In Durham, plants that survived were small and weak in the spring, and none produced marketable bulbs by the conclusion of the experiment.
However, in North Haverhill onion plants grown outdoors did produce large bulbs (Table 8 ). These bulbs were slightly later to mature and were $20 \%$ to $25 \%$ smaller in diameter than those grown under low tunnels. When grown without low tunnels, bulb size was consistently larger for the earlier planting date than for the later planting date. Further, at the later harvest dates, 'Walla Walla' bulbs were significantly larger than 'Bridger' bulbs.

\section{Discussion}

Our work confirms that onion cultivar selection is critical to ensure success with an overwintering

Table 7. Mean bulb diameter for several cultivars of fall-planted onion grown in low tunnels in Durham, NH, in the 2012-13 season.

\begin{tabular}{|c|c|c|c|c|c|c|}
\hline & \multicolumn{6}{|c|}{ Mean bulb diam $(\mathrm{mm})^{\mathrm{z}}$} \\
\hline & \multicolumn{2}{|c|}{22 May harvest ${ }^{\mathrm{y}}$} & \multicolumn{2}{|c|}{3 June harvest } & \multicolumn{2}{|c|}{20 June harvest } \\
\hline & Early $^{x}$ & Late & Early & Late & Early & Late \\
\hline Bridger & $49.3 b^{w}$ & $36.1 \mathrm{a}$ & $59.8 \mathrm{~b}$ & $51.3 \mathrm{a}$ & $75.0 \mathrm{~b}$ & $68.3 \mathrm{a}$ \\
\hline Keepsake & $60.7 \mathrm{a}$ & $38.8 \mathrm{a}$ & $75.6 \mathrm{a}$ & $52.2 \mathrm{a}$ & $84.8 \mathrm{a}$ & $69.5 \mathrm{a}$ \\
\hline $\mathrm{T}-420$ & $60.1 \mathrm{a}$ & $37.0 \mathrm{a}$ & $66.8 \mathrm{ab}$ & $52.0 \mathrm{a}$ & $85.0 \mathrm{a}$ & $66.0 \mathrm{a}$ \\
\hline Winter White & $36.2 \mathrm{c}$ & $22.6 \mathrm{~b}$ & $46.9 \mathrm{c}$ & $31.0 \mathrm{~b}$ & $60.5 c$ & $53.1 \mathrm{~b}$ \\
\hline Overall mean & 51.4 & 32.9 & 62.2 & 46.0 & 78.8 & 64.7 \\
\hline \multicolumn{7}{|l|}{ Analysis of variance ${ }^{v}$} \\
\hline Cultivar & \multicolumn{2}{|c|}{$* * *$} & \multicolumn{2}{|c|}{$* * *$} & \multicolumn{2}{|c|}{$* * *$} \\
\hline Transplant date & \multicolumn{2}{|c|}{$* * *$} & \multicolumn{2}{|c|}{$* * *$} & \multicolumn{2}{|c|}{$* * *$} \\
\hline
\end{tabular}

${ }^{\mathrm{z}} 1 \mathrm{~mm}=0.0394$ inch

y subsample of six plants from each plot was harvested on each of three dates in both locations.

${ }^{x}$ Results for each transplant date are presented separately only when a significant cultivar $\times$ planting date interaction was identified. The early and late transplant dates were 20 Sept. and 20 Oct., respectively.

"Within a column, means followed by the same letter are not significantly different at $P \leq 0.05$ using Tukey's honestly significant difference test.

${ }^{v} \mathrm{NSD}=$ no significant differences detected, ${ }^{* *} P<0.001,{ }^{*} P<0.01,{ }^{*} P<0.05$.

Table 8. Mean bulb diameter for fall-planted onion grown in low tunnels or outdoors without protection in North Haverhill, $\mathrm{NH}$, in the 2012-13 season.

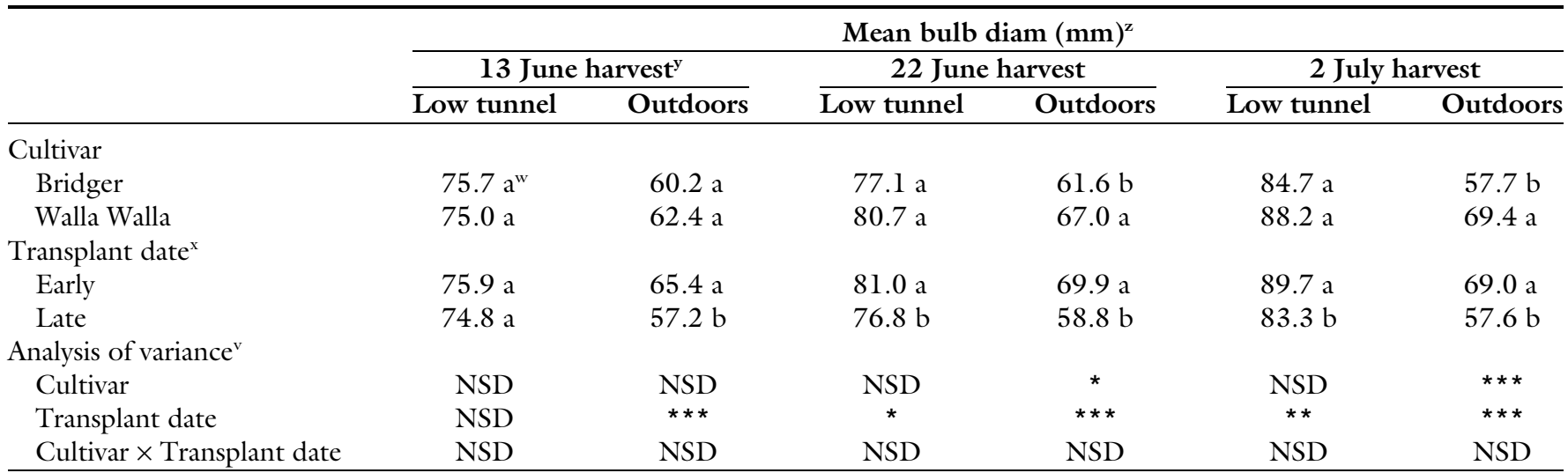

${ }^{\mathrm{z}} 1 \mathrm{~mm}=0.0394$ inch

y subsample of six plants from each plot was harvested on each of three dates.

xThe early and late transplant dates were 11 Oct. and 21 Oct., respectively.

"Within a column, means followed by the same letter are not significantly different at $P \leq 0.05$ using Tukey's honestly significant difference test.

${ }^{\mathrm{N} S D}=$ no significant differences detected, ${ }^{* * *} P<0.001,{ }^{* *} P<0.01,{ }^{*} P<0.05$. 
production system in cold climates. Of the cultivars evaluated, several yellow cultivars (Bridger, T-420, Top-Keeper, and Keepsake) exhibited good survival over winter (over 85\%) and showed relative resistance to bolting compared with the cultivar Walla Walla. Of these cultivars, Bridger may be the best suited for this system now, because it had the lowest percentage of bolting in several experiments, and is available to producers, as it is currently widely grown in typical spring plantings. 'Walla Walla' performed inconsistently, producing large bulbs and very little bolting in 1 year, but showing almost $100 \%$ bolting in the other year.

In our study, we did not see evidence that cultivars differed in winterhardiness, and in general, survival was high, despite minimum temperatures as low as $-28^{\circ} \mathrm{C}$. Gill and Waister (1983) proposed that frost heaving, and the corresponding damage caused to roots, was an important factor in causing death of overwintered onion in Scotland. The combination of black plastic mulch and protection by low tunnels prevented the soil temperature from going below freezing in most cases. It is likely that freeze-thaw cycles were greatly reduced in this protected environment. Onion plants overwintered without the protection of low tunnels showed poor survival in one experiment, but good survival in the other. This may have been due to more consistent snow cover in the colder environment, but the North Haverhill site was also more protected from wind than the Durham site. While inconsistent results suggest that this is not a practice that should be recommended due to the risks, it is noteworthy that onion plants survived much colder temperatures than the literature would suggest.

In the warmer locations where onion is routinely grown overwinter or where field production has been previously explored, plants are sown directly. In our experiments, we used transplants, which are also typically used in New England for spring production. This permits longer use of fields for preceding crops and also minimizes the influence of fall weather on seedling development. Still, our results are consistent with Brewster (2008) and Corgan and Keder (1990), both of which describe tradeoffs between a lower risk of bolting and higher risk of winter mortality with later sowing dates in the United Kingdom and New Mexico, respectively. We also demonstrated that the ultimate yield potential of onion in the spring was dependent on fall transplant date, with earlier plantings (and larger plants) producing larger bulbs.

While low tunnels reduced exposure to lethal winter temperatures, they also increased exposure to vernalization temperatures, increasing the likelihood of bolting. However, low tunnels also created conditions where devernalization could have occurred, particularly in early spring. Yamasaki et al. (2003) described the use of tunnels to increase temperatures and devernalize field-grown scallion to reduce spring bolting. Devernalization may have occurred in our study, but it is also possible that plants that did not bolt had simply not been completely vernalized. Although we presented monthly accumulation of vernalization temperatures, our transplants were quite small and likely still in the juvenile stage during the fall months, so the actual amount of vernalization temperature received once plants were beyond the juvenile stage is not known. With additional research, it is likely that the chances of bolting could be reduced through a combination of manipulating dates of fall planting, low tunnel installation, and low tunnel removal.

All plants that survived the winter and that did not bolt produced a marketable bulb. For 'Bridger', 'T420', 'Top-Keeper', 'and 'Keepsake', $85 \%$ to $100 \%$ of the plants met these criteria, which corresponds to a potential yield of 37,000 to 43,500 bulbs/acre. While this is considerably lower than expected yields for major onion production regions, these yields may be commercially viable in a high-value direct-market situation. Direct-market sales are the primary outlet for growers in our region, and these off-season onions would likely be sold individually at sizes determined by local market preferences.

Diseases and insects did not present problems in our experiments. A low level of onion thrips was observed, but it did not exceed management thresholds. Aphids were observed inside the low tunnels in spring, primarily on winter annual weeds, but they were not observed on onion plants. The black plastic mulch and light hand weeding was sufficient to remove weeds from this production system with minimal labor.

We have shown that it is possible to harvest high-quality, large onion bulbs in May and June in cold climates in the northeastern United States by using low tunnels and have identified cultivars and target transplant dates as a starting point for future work. Russo and Shefler (2012) also experimented with using season extension structures for onion production, demonstrating that scallion can be grown over winter months in hoop houses or greenhouses to meet local demand in Oklahoma. The costs of establishing low tunnels will likely make this system most feasible when locally produced onions in early summer receive a price premium or when having an additional product to sell enhances marketing opportunities.

\section{Literature cited}

Allen, E.J., J.L. Jones, and P.J. Salter. 1978. Effects of date of sowing on overwintered onion varieties in Pembrokeshire. J. Agr. Sci. Cambridge 90:237239.

Baldwin, S., R. Revanna, M. Pither-Joyce, M. Shaw, K. Wright, S. Thomson, L. Moy, R. Lee, R. Macknight, and J. McCallum. 2014. Genetic analysis of bolting in bulb onion (Allium cepa L.). Theor. Appl. Genet. 127:535-547.

Bosch Serra, A.D. and L. Currah. 2002. Agronomy of onions, p. 187-232. In: H.D. Rabinowitch and L. Currah (eds.). Allium crop science: Recent advances. CABI Publ., Wallingford, U.K.

Boyhan, G.E., R.L. Torrance, J. Cook, C. Riner, and C.R. Hill. 2009. Sowing date, transplanting date, and variety effect on transplanted short-day onion production. HortTechnology 18:145-151.

Brewster, J.L. 1982. Flowering and seed production in overwintered cultivars of bulb onions, I. Effects of different raising environments, temperatures and daylengths. J. Hort. Sci. 57:93-101.

Brewster, J.L. 2008. Onions and other vegetable alliums. 2nd ed. CABI Publ., Wallingford, U.K.

Brewster, J.L., P.J. Salter, and R.J. Darby. 1977. Analysis of the growth and yield of overwintered onions. J. Hort. Sci. 52:335346. 


\section{Research Reports}

Corgan, J.N. and N. Keder. 1990. Onion cultivation in subtropical climates, p. 3148. In: H.D. Rabinowitch and J.L. Brewster (eds). Onions and allied crops, vol. 2, CRC Press, Boca Raton, FL.

Corgan, J.N., M.M. Wall, C.S. Cramer, T. Sammis, B. Lewis, and J. Schroeder. 2000. Bulb onion culture and management. New Mexico Coop. Ext. Serv. Circ. 563.

Cramer, C.S. 2003. Performance of fallsown onion cultivars using four seeding dates. J. Amer. Soc. Hort. Sci. 128:472478 .

Gill, P.A. and P.D. Waister. 1983. Winter hardiness in autumn-sown onions ( $\mathrm{Al}$ lium cepa L.) Crop Res. (Hort. Res.) 23:17-31.

Hemphill, D.D. 1987. Overwintering onions and other alliums in the Willamette Valley. Oregon Agr. Expt. Sta. Spec. Rpt. No. 794. 18 Aug. 2014. <http://nwrec. hort.oregonstate.edu/owonion.html>.
Howell, J. and R. Hazzard. 2011. 20122013 New England vegetable management guide. Univ. Massachusetts Ext. Publ. 18 Aug. 2014. <https://nevegetable. org/crops/varieties-10>.

Pike, L.M. 1986. Onion breeding, p. 357394. In: M.J. Bassett (ed.). Breeding vegetable crops. AVI Publishing, Westport, CT

Rice, G. 2010. An international perspective on hardiness ratings. Plantsman (Lond., Engl.) 9:118-119.

Russo, V.M. and J. Shrefler. 2012. Bunching onion culture in greenhouse and hoop house. HortScience 47:15641568 .

Sideman, R.G., A. Brown, C.A. Martin, R. Hazzard, and A. Cavanagh. 2012. Temperature moderating effects of low tunnels over winter in cool climates. HortScience 47:S404-S405 (abstr.).
Streck, N.A. 2012. A vernalization model in onion (Allium cepa L.). Revista Brasileira Agrociencia 9:99-105.

U.S. Department of Agriculture. 2012. USDA plant hardiness zone map. 18 Aug. 2014. <http://planthardiness.ars.usda. gov $/>$.

Yamasaki, A., K. Tanaka, and N. Nakashima. 2003. Effect of photoperiod on the induction of devernalization by high day temperature in field-grown japanese bunching onion (Allium fistulosum L.). J. Jpn. Soc. Hort. Sci. 72:18-23. 